\title{
GEOCHEMICAL STRATIGRAPHY OF THE PARANÁ CONTINENTAL FLOOD BASALTS: BOREHOLE EVIDENCE
}

\author{
DAVID W. PEATE*, MARTA S.M. MANTOVANI** and CHRIS J. HAWKESWORTH*
}

\begin{abstract}
Stratigraphic studies can provide an insight into the poorly understood geodynamic processes for the generation and emplacement of large continental flood basalt provinces by revealing the structure and sequential evolution of the lava field. Such studies are still in their infaney in the Paraná, where lack of sufficient topographic relief has confined work mainly to the well-exposed coastal escarpment in south-east Brazil. In this paper, a new approach is taken by analysing drillcore chippings from four oil-company boreholes in the central Paraná basin. Major and trace element analyses distinguish three geochemical units by their low, intermediate, and high $\mathrm{TiO}_{2}$ contents.respectively, and demonstrate the validity of geochemical data from such material. Each borehole retains a coherent stratigraphy with the transition from low- $\mathrm{Ti}$ to high-Ti then intermediate-Ti lavas with time, and together they show an overlapping sequence of geochemical units dipping northwards, which could suggest a northward migrating source for the Paraná magmatism in this central-north region. The available data on geochemical stratigraphy of the Parana, is summarised in a north-south cross-section through the lava field that shows the salient features of the Parana stratigraphy; the stacking of units in the northern boreholes; the complex transition between low-Ti and high-Ti magma types in the coastal profiles of Santa Catarina state; and the concentration of acidic volcanics along the present day continental margin.
\end{abstract}

RESUMO ESTRATIGRAFIA GEOOUIMICA DOS DERRAMES BASÁLTICOS CONTINENTAIS DA BACIA DO PARANA: EVIDENCIAS DE FUROS DE SONDAGEM. O estudo estratigráfico das grandes províncias de basaltos continentais permite inferir a estrutura e a evolução seqüencial do vulcanismo, visando uma melhor compreensāo dos processos geodinâmicos que geraram e provocaram a erupçāo de suas lavas. No caso da província de basaltos continentais da Bacia do Paraná, tais estudos permaneceram até agora confinados à parte SE, em território brasileiro, única regiäo em que a Formaçāo Serra Geral é exposta ao longo da escarpa costeira. No presente trabalho, apresenta-se uma anál se estratigráfica em amostras de calha extraídas de furos de sondagens para exploraçäo de petróleo, situados na regiāo central da Bacia do Paraná. As análises de elementos maiores e traços permitiram distinguir três unidades geoquímicas em relaçăo a seu conteúdo de $\mathrm{TiO}_{2}$ (baixo, intermediário e alto), e demonstrar a validade dos dados geoquímicos no material utilizado. A estratigrafia em cada perfuração se mantém coerente com uma transição de lavas de baixo Ti para alto Ti e para Ti intermediário, com o passar do tempo; observa-se uma superposiçāo das unidades geoquímicas com mergulho para o norte, o que sugere uma migraçāo do vulcanismo da regiāo central do Paraná em direção ao norte. Os dados disponíveis de estratigrafia geoquímica das vulcânicas efusivas da Bacia do Paraná săo representados numa secção N-S da Formação Serra Geral, onde se observam: o empilhamento das unidades nas perfurações mais ao norte; a complexa transiçāo entre os tipos de magmas de alto Ti nos perfis costeiros do Estado de Santa Catarina; e a concentração das vulcânicas ácidas ao longo da atual margem continental.

\section{INTRODUCTION Stratigraphy}

Importance

of

Chemical Investigations into the origin of continental flood basalts (CFB) have in recent years focused largely on the interpretation of the trace element and isotope enrichments that are a marked feature of these rocks. Such large CFB provinces (e.g. Paraná, Karoo, Deccan) are also problematical with respect to the understanding of mechanisms for their emplacement, especially in the absence of any true modern day analogues. Stratigraphy studies of lava sequences within these provinces have begun to shed light on such problems, revealing the spatial and temporal variations needed to constrain models for the geodynamic evolution of the magmatism.

The angles of dip of the lavas, typically $<2^{\circ}$, are too small to be discerned in the field and so to determine the regional dip it is necessary to establish an internal stratigraphy by correlating individual flows or packets of flows on a regional scale. In developing a stratigraphic classification scheme, it is necessary to be able to characterise and distinguish groups of flows despite of the general monotonous laver-cake field appearance of continental flood basalts (CFB) lava sequences. Field criteria and petrographic evidence have proved to be of limited value in correlating flows on a regional scale because of the broad similarities between flows, and the variability found within individual flows due to differing amounts of weathering, phenocryst content, and degree of vesicularity. A more successful approach has been to use the chemical composition of the flows in order to divide the lava pile into discrete geochemical formations or units. Using this method, extensive geochemically distinct units have been traced out in both the Columbia River basalts (Swanson et al. 1979) and the Deccan Trap Lavas (Cox \& Hawkesworth 1985, Beane et al. 1986, Devey \& Lightfoot 1986).

A geochemical unit or formation is defined as a packet of lava flows of a given magma type, where a magma type represents a distinct parental magma reaching the upper crust. A wide range of trace elements (concentrations and ratios) and isotope ratios are used to assign flows to a specific formation. In choosing such criteria, their effectiveness in defining, and distinguishing between, formations must be considered. This requires a good understanding of inter- and intra-flow chemical variation, with detailed studies of flow heterogeneity and element mobility during post-solidification alteration. The underlying causes for the major chemical changes within the lava pile; e.g. variations in the mantle source region and/or degree of crustal contamination are not the immediate concern in establishing a chemical stratigraphic classification. Magmas within a suite will all have suffered varying degrees of crystal fractionation and to minimise the effects of this fractionation, incompatible element or isotope ratios are more useful when defining geochemical units.

Once a regionally applicable stratigraphic scheme is established, the lithostratigraphic pattern of the geochemical units can reveal the internal structure of the lava pile. Before 
any discussion of the geodynamic implications of such a configuration of units, the first concern must be whether the structure is a secondary feature resulting from post-eruption uplift and deformation or whether it is essentially a primary volcanic feature. Analysis of the lateral distribution and thickness variations of individual formations will be important in this evaluation. Any interpretation of the structure of the province must then be viewed in the context of the regional tectonic setting.

Geochemical stratigraphy has allowed two different styles of magma emplacement to be recognised in the Deccan and Karoo continental flood basalts (CFB) provinces respectively, and the generalised stratigraphic patterns for the two areas are illustrated in figure 1. For the Deccan basalts,
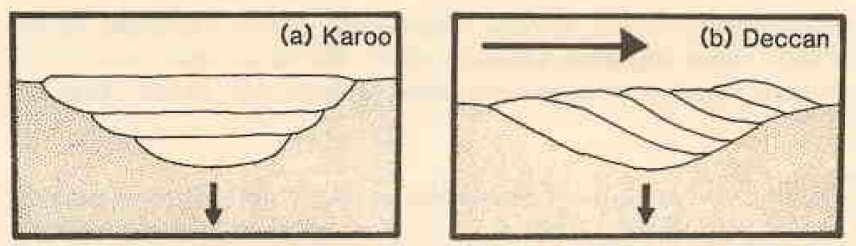

Figure 1 - Generalised stratigraphic patterns for (a) Karoo and (b) Deccan continental fiood basalts (CFB) provinces after Lighfloot (1985). a. Karoo - sub-horizontal stacking of formations due lithostatic loading, suggesting a stationary source and feeder system. b. Deccan - en-échelon overlapping of successive formations, attributed to a migration magmatic source (Devey \& Lightfoot 1986)

stratigraphic studies (Beane et al. 1986, Devey \& Lighfoot 1986) have revealed an en-échelon pattern of successively younger units overlapping to the south, which has been attributed to a southwardly migrating magmatic source arising from the northward drift of the Indian continent over the Reunion "hot spot". An alternative to this "Deccan-model" is needed to explain the contrasting structure of the Karoo province, where the lavas display a horizontal layer-cake stratigraphy. This could be a consequence of having an essentially stationary magmatic source and feeder system.

\section{BACKGROUND GEOLOGY The Paraná magmatism} represents one of the largest continental flood basalt (CFB) provinces in the world, having a present day extent of $1,200,000 \mathrm{~km}^{2}$ (Maack 1952) that covers most of southern Brazil and extends into Paraguay, Uruguay, and Argentina (cf. Karoo $140,000 \mathrm{~km}^{2}$ and Deccan $500,000 \mathrm{~km}^{2}$ ). The abundant dykes and basalts outliers suggest a possible original area of close to $2,000,000 \mathrm{~km}^{2}$, and an estimate of $660 \mathrm{~m}$ (Leinz et al. 1966) for the average thickness over the province gives a total lava volume of at least $790,000 \mathrm{~km}^{3}$. The lavas are dominated by tholeiitic basalts $(>90 \%)$ though important but minor sequences of acidic and scarce intermediate lavas occur in the south-east corner of the lava field. The acidic volcanics (rhyodacites and rhyolites) typically form the uppermost stratigraphic layers and are found up to $400 \mathrm{~m}$ thick in places (Bellieni et al. 1986).

The Serra Geral lavas were erupted during the Early Cretaceous, covering the preexisting Parana sedimentary basin that had developed after the events of the Brasiliano cycle (700-450 Ma). The lavas immediately overlie the Botucatu Formation, a continental aeolian sequence of dune crossbedded sandstones that also form intercalations of 2-20 $\mathrm{m}$ within the basalt sequence. $\mathrm{K}$ - Ar ages of the basalts cluster in the range 115-135 Ma (Amaral et al. 1966, Melfi et al. 1967) with a preferred age of $130 \mathrm{Ma}$.

The Parana basalts have been divided into two groups based on their $\mathrm{Ti}$ and $\mathrm{P}$ contents (Bellieni et al. 1984
Mantovani et al. 1985a). The LPT (low P and Ti) suite is characterised by $<2$ wt\% $\mathrm{TiO}_{2}$ and $<0.35$ wt $\% \mathrm{P}_{2} \mathrm{O}_{5}$ whereas the HPT (high $\mathrm{P}$ and $\mathrm{Ti}$ ) suite has $>3 \mathrm{wt} \% \mathrm{TiO}_{2}$ and $>0.4 w i \% \mathrm{P}_{2} \mathrm{O}_{5}$. This difference is also reflected in certain incompatible element contents, HPT having higher LREE, Sr, $\mathrm{Ba}, \mathrm{Zr}$, and $\mathrm{Nb}$ than $\mathrm{LPT}$ rocks of similar $\mathrm{MgO}$ content. The chemical diversity within each group has been shown, using major element modelling techniques, to be consistent with low pressure fractional crystallization of the observed phenocryst phases (ol/cpx/plag/Fe-Ti oxides). However, differences in trace element contents between the two groups rule out the derivation of HPT lavas from a parental LPT magma by crystal fractionation. The origin of both HPT and LPT magmas from different mantle source regions is favoured by both Bellieni et al. (1984) and Mantovani et al. (1985a), who also state that the dominance of HPT rocks in the north and LPT in the south suggests the presence of large scale lateral variations within the upper mantle beneath Brazil. On the other hand, Fodor (1987) has recently argued that both groups could be generated by different degrees of partial melting of a single mantle source (LPT-25\%, HPT-11\%), relating this difference to varying proximity from the Tristão da Cunha "hot spot" which was probably located beneath the present-day Torres-Posadas syncline at about $150 \mathrm{Ma}$.

Within both groups, geographical variations of lava chemistry have been noted. There is a difference between HPT lavas in the north and south-central areas of the lava field with the southern lavas enriched slightly in $\mathrm{Ti}, \mathrm{Nb}$, and $\mathrm{Zr}$ (Bellieni et al. 1984). Similarly within the LPT sequence in Rio Grande do Sul state, two sub-groups have been distinguished on their $\mathrm{K}_{2} \mathrm{O}, \mathrm{Rb}$, and $\mathrm{Ba}$ contents by Fodor $e$ t al. (1985), who suggest that they most likely represent magmas originating from a similar source region but differing due to the extent of crustal contamination suffered en route to the surface. More recent work (Piccirillo et al. 1986) has shown that there is a third major group, IPT, having Ti and P contents intermediate to LPT and HPT, i.e. TiO, 2-3 wt\%. The existence of such geochemically distinct groups within the Paraná basalts encourages a stratigraphic investigation of these sequences in order to unravel the magmatic evolution of this extensive province.

In contrast to the better known Deccan, Karoo, and Columbia River provinces, stratigraphic studies of the flood basalt sequences in the Paraná are still in their early stages with little consensus on the classification and nomenclature of geochemical units. The ease of stratigraphic work is dictated largely by the physiography of the lava field. In the Paraná region, the greater part of the lava field is devoid of suitable sections for stratigraphic sampling as sufficient topographic relief is rarely developed. There is a lack of major incised rivers, and no escarpment is developed west in Paraguay and to the north in Mato Grosso do Sul and São Paulo states. Work is further hampered in the northwest, and south in Argentina, by an extensive cover of late Cretaceous sediments (Bauru Formation) that obscures over a third of the total lava field (Schobbenhaus et al. 1984). Hence sampling over most of the province has mainly been of surface samples with little or no stratigraphic control. Because of these problems, most workers have concentrated on the extreme south-east of the province where the lavas form an escarpment, the "Serra Geral". This escarpment, reaching a maximum height at Morro da Igreja of $1,820 \mathrm{~m}$, is marked by a sudden rise of $800-1,000 \mathrm{~m}$ from the coastal plain up to the flat lying lava plateau. Stratigraphic sections are restricted to road sections cutting the escarpment because of the dense vegetation cover and the often precipitous drop! On the coastal Serra Geral section in southern Santa Catarina and Rio Grande do Sul states, this leads to exposed lava thicknesses of $750-800 \mathrm{~m}$ although once the escarpment turns inland this thickness decreases to $350-400 \mathrm{~m}$ (Piccirillo et al. 1986). Considering 
the huge areal extent of the Parana magmatic event, the biasing of available stratigraphic data to such a restricted area within the province places severe limitations on any interpretation regarding models for its geodynamic evolution. When samples from Petrobrás oil exploration boreholes in the central regions of the plateau became available to one of the authors (MSMM, Mantovani et al. 1988), this provided an opportunity to investigate the geochemical stratigraphy of an otherwise inaccessible area.

BOREHOLES The presence of a sedimentary basin beneath the Paraná flood basalts prompted an extensive exploration drilling programme by Brazilian oil companies during the 1960's and 1970's. This work (Northfleet et al. 1969, Schneider et al. 1974, Paulipetro 1982, Zalan 1987), has led to a reasonable three-dimensional picture of the structure of both the basin and the overlying lavas. Figure 2 is

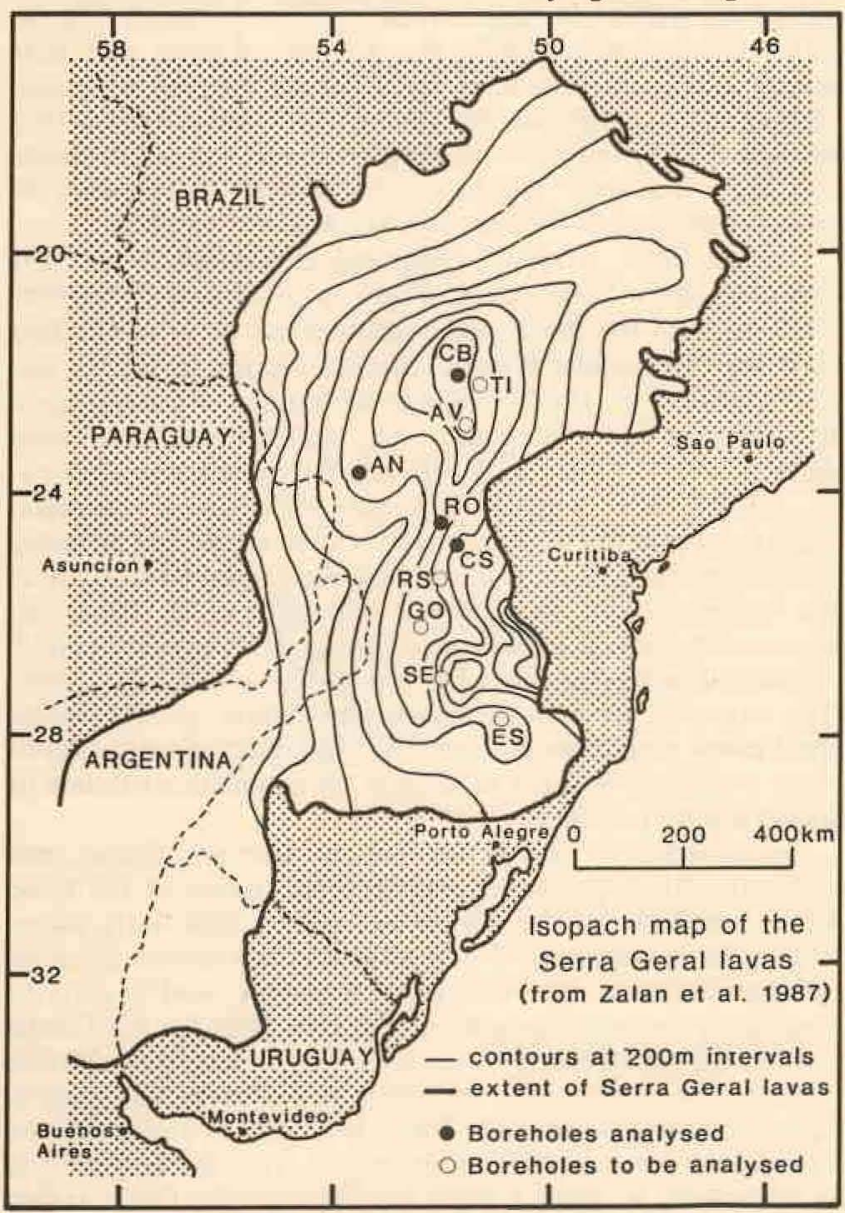

Figure 2 - Isopach map of lava thickness and areal extent, from Zalan et al. (1987). Locations of the studied boreholes (solid circles), and those being analysed (open circles) are shown

an isopach map for the Serra Geral Formation, and shows how the variation in lava thickness over the basin mirrors the overall structure of the underlying sedimentary basin. The lavas reach a maximum thickness $(>1.5 \mathrm{~km})$ in the northern basin, with the main axis of lava thickness $(>1 \mathrm{~km})$ running down the central area, roughly parallel to the northeast-southwest elongation of the basin. There is an anomalously thick sequence in the south-east corner onshore of the Rio Grande Rise and coincident with the Torres-Posadas syncline. Previous work on boreholes samples in the Paraná has concentrated on a few cored samples of the lavas (K-Ardates, Melfi et al. 1967) and of sills intruded into the Palaeozoic sediments (Bellieni et al. 1984). The data-set in Mantovani et al. (1985a) includes two IPT lava flow samples from boreholes in central Paraná ("SP" $550 \mathrm{~m}$ depth; "PR" $110 \mathrm{~m}$ depth), which were analysed for major and trace elements as well as for $\mathrm{Sr}$ isotopic compositions. In addition, Mantovani (1985) analysed both samples for $\mathrm{Pb}$ and the SP511 for Nd isotopic compositions.

In this study, samples were selected from 10 wells that had been chosen in order to give a roughly north-south profile from $22^{\circ} \mathrm{S}$ to $28^{\circ} \mathrm{S}(\sim 650 \mathrm{~km}$ ) following as closely as possible the main axis of lava thickness. The locations are given on figure 2 , and details in table 1 . The most southerly borehole, "ES", lies only about $120 \mathrm{~km}$ east of the northern part of the Serra Geral escarpment and should provide a tie-in with the detailed data available for the coastal road sections (Mantovani et al. 1985a, Mantovani 1985, Piccirillo et al. 1986, Peate unpub.). Unfortunately the lavas were not cored during drilling, and the available samples are in the form of

Table 1 - Location of boreholes studied; elevations in meters above sea level. Thickness of the Serra Geral Formation (basalts) and the overlying Bauru Formation (siltstones/sandstones) in meters (taken from geophysical well-logs). Depth down borehole to sills within the Palaeozoic sediments of the Paraná Basin. In all boreholes, the Serra Geral basalts overlie the Botucatu Formation (aeolian sandstones)

\begin{tabular}{|c|c|c|c|c|}
\hline $\begin{array}{l}\text { Borehole } \\
\text { Locations }\end{array}$ & $\mathrm{CB}$ & AN & RO & CS \\
\hline Code & 2-CB-1-SP & 2-AN-1-PR & 1-RO-1-PR & 1-CS-2-PR \\
\hline Situation & $\begin{array}{l}\text { Cuiabá } \\
\text { Paulista }\end{array}$ & Altônia & Roncador & $\begin{array}{l}\text { Chapéu } \\
\text { do Sol }\end{array}$ \\
\hline State & Såo Paulo & Paraná & Paraná & Paraná \\
\hline Latitude & $22^{\circ} 18^{\prime} 11,9^{\prime \prime} \mathrm{S}$ & $23^{\circ} 51^{\prime} 16^{\prime \prime} \mathrm{S}$ & $24^{\circ} 36^{\prime} 33^{\prime \prime} \mathrm{S}$ & $24^{\circ} 58^{\prime} 50^{\prime \prime} \mathrm{S}$ \\
\hline Longitude & $52^{\circ} 02^{\prime} 21,6^{\prime \prime} \mathrm{W}$ & $53^{\circ} 48^{\prime} 27^{\prime \prime} \mathrm{W}$ & $52^{\circ} 14^{\prime} 48^{\prime \prime} \mathrm{W}$ & $51^{\circ} 56^{\prime} 35^{\prime \prime} \mathrm{W}$ \\
\hline Elevation & $396 \mathrm{~m}$ & $410 \mathrm{~m}$ & $748 \mathrm{~m}$ & $913 \mathrm{~m}$ \\
\hline $\begin{array}{l}\text { Thickness } \\
\text { Fm Bauru } \\
\text { Fm Serra } \\
\text { Geral }\end{array}$ & $\begin{array}{c}207 \mathrm{~m} \\
1,723 \mathrm{~m}\end{array}$ & $\begin{array}{c}262 \mathrm{~m} \\
1,072 \mathrm{~m}\end{array}$ & $\begin{array}{l}\text { Absent } \\
1,248 \mathrm{~m}\end{array}$ & $\begin{array}{l}\text { Absent } \\
933 \mathrm{~m}\end{array}$ \\
\hline Sills at & $\begin{array}{c}3,018-3,115 \mathrm{~m} \\
3,245-3,350 \mathrm{~m} \\
4,416-4,430 \mathrm{~m} \\
4,453-4,796 \mathrm{~m} \\
5,125-? \mathrm{~m}\end{array}$ & $\begin{array}{l}2,870-3,050 \mathrm{~m} \\
3,120-3,235 \mathrm{~m} \\
3,408-3,415 \mathrm{~m} \\
3,420-3,645 \mathrm{~m} \\
4,735-5,005 \mathrm{~m} \\
5,425-5,455 \mathrm{~m}\end{array}$ & $\begin{array}{l}3,535-3,555 \mathrm{~m} \\
3,708-3,772 \mathrm{~m} \\
3,835-3,957 \mathrm{~m} \\
4,015-4,045 \mathrm{~m} \\
4,170-4,295 \mathrm{~m}\end{array}$ & $\begin{array}{l}2,468-2,585 \mathrm{~m} \\
3,035-3,080 \mathrm{~m} \\
3,658-3,748 \mathrm{~m}\end{array}$ \\
\hline $\operatorname{Minor}(<5 \mathrm{~m})$ & & $5,215 \mathrm{~m}$ & & $1,980 \mathrm{~m}$ \\
\hline Sills at & & $5,425 \mathrm{~m}$ & & $\begin{array}{l}2,161 \mathrm{~m} \\
3,008 \mathrm{~m} \\
3,085 \mathrm{~m} \\
3,092 \mathrm{~m}\end{array}$ \\
\hline
\end{tabular}

small rock chips 0.1 to $1 \mathrm{~cm}$ in size. Sample selection from each borehole was made after taking into account the geophysical well-log data and the quality of the collected material. Geophysical data from the well-logs give an estimate of the position of the contact between successive data flows. The nature of the available samples, the limited sample size, and collection over a certain thickness range in the borehole makes it difficult to assess the extent of within-flow variation caused by in situ differentiation and/or varying degrees of alteration. Each sample represents an accumulation of rock fragments from at least a 3-4 m depth range in the drillhole and so analyses will be an average over this range of lava thickness. Because of these problems, each sample was carefully handpicked, firstly to avoid any fragments with vesicular fillings (calcite, zeolite, quartz, agate) or that showed any signs of mineralisation or alteration, and secondary to try and ensure that all of the 
Table 2 - Selected geochemical analyses of the units encountered in the boreholes. Samples names consist of the borehole name followed by the depth of collection in metres down the borehole

\begin{tabular}{|c|c|c|c|c|c|c|c|c|c|c|c|c|c|c|c|}
\hline Boreholes & $\begin{array}{l}\text { CS900 } \\
\text { LPT }\end{array}$ & $\begin{array}{l}\text { CS657 } \\
\text { LPT }\end{array}$ & $\begin{array}{c}\text { AN783 } \\
\text { IPT }\end{array}$ & $\begin{array}{c}\text { RO57 } \\
\text { IPT }\end{array}$ & $\underset{\text { IPT }}{\text { RO381 }}$ & $\begin{array}{l}\text { AN657 } \\
\text { IPT }\end{array}$ & $\begin{array}{c}\text { AN585 } \\
\text { IPT }\end{array}$ & $\begin{array}{c}\text { CB276 } \\
\text { IPT }\end{array}$ & $\begin{array}{c}\text { CB1002 } \\
\text { IPT }\end{array}$ & $\begin{array}{c}\text { CB846 } \\
\text { HPT }\end{array}$ & $\underset{\text { HPT }}{\text { CB1362 }}$ & $\underset{\text { HPT }}{\text { CB1110 }}$ & $\begin{array}{c}\text { RO759 } \\
\text { HPT }\end{array}$ & $\begin{array}{l}\text { CB1902 } \\
\text { HPTen }\end{array}$ & $\begin{array}{l}\text { CB1776 } \\
\text { HPTen }\end{array}$ \\
\hline $\begin{array}{l}\mathrm{SiO}_{2} \\
\mathrm{TiO}_{2} \\
\mathrm{Al}_{2} \mathrm{O}_{3} \\
\mathrm{Fe}_{2} \mathrm{O}_{3} \\
\mathrm{MnO} \\
\mathrm{MgO} \\
\mathrm{CaO} \\
\mathrm{Na}_{2} \mathrm{O} \\
\mathrm{K}_{2} \mathrm{O} \\
\mathrm{P}_{2} \mathrm{O}_{5}\end{array}$ & $\begin{array}{r}54.58 \\
1.41 \\
13.95 \\
12.14 \\
0.20 \\
4.96 \\
8.75 \\
2.76 \\
1.33 \\
0.21\end{array}$ & $\begin{array}{r}52.58 \\
1.96 \\
13.09 \\
15.06 \\
0.22 \\
4.46 \\
8.84 \\
2.47 \\
1.04 \\
0.28\end{array}$ & $\begin{array}{r}50.42 \\
1.82 \\
13.82 \\
13.45 \\
0.20 \\
6.06 \\
10.60 \\
2.63 \\
0.80 \\
0.20\end{array}$ & $\begin{array}{r}50.27 \\
2.01 \\
13.56 \\
13.99 \\
0.22 \\
6.28 \\
10.35 \\
2.34 \\
0.65 \\
0.32\end{array}$ & $\begin{array}{r}49.51 \\
2.34 \\
13.52 \\
14.29 \\
0.22 \\
5.27 \\
9.66 \\
3.34 \\
1.50 \\
0.36\end{array}$ & $\begin{array}{r}50.43 \\
2.39 \\
13.06 \\
15.23 \\
0.23 \\
4.82 \\
9.21 \\
3.22 \\
1.06 \\
0.31\end{array}$ & $\begin{array}{r}50.41 \\
2.47 \\
13.00 \\
15.51 \\
0.21 \\
4.45 \\
8.47 \\
3.69 \\
1.46 \\
0.31\end{array}$ & $\begin{array}{r}50.79 \\
3.17 \\
11.80 \\
17.03 \\
0.26 \\
4.06 \\
8.02 \\
2.77 \\
1.72 \\
0.38\end{array}$ & $\begin{array}{r}50.70 \\
2.75 \\
12.81 \\
15.43 \\
0.22 \\
4.39 \\
8.60 \\
3.00 \\
1.44 \\
0.65\end{array}$ & $\begin{array}{r}49.75 \\
3.15 \\
13.09 \\
15.31 \\
0.23 \\
4.92 \\
9.34 \\
2.50 \\
1.25 \\
0.48\end{array}$ & $\begin{array}{r}49.79 \\
3.66 \\
12.84 \\
15.22 \\
0.21 \\
4.75 \\
9.13 \\
3.18 \\
0.74 \\
0.47\end{array}$ & $\begin{array}{r}51.27 \\
3.35 \\
12.70 \\
14.96 \\
0.23 \\
4.34 \\
8.56 \\
3.02 \\
1.05 \\
0.54\end{array}$ & $\begin{array}{r}52.43 \\
3.28 \\
12.33 \\
15.05 \\
0.22 \\
3.17 \\
7.44 \\
3.14 \\
2.04 \\
0.92\end{array}$ & $\begin{array}{r}49.27 \\
3.91 \\
12.81 \\
14.79 \\
0.19 \\
5.75 \\
8.46 \\
2.83 \\
1.51 \\
0.49\end{array}$ & $\begin{array}{r}49.75 \\
3.88 \\
14.39 \\
13.97 \\
0.17 \\
4.17 \\
7.83 \\
3.11 \\
2.16 \\
0.55\end{array}$ \\
\hline & $\begin{array}{l}0.40 \\
48.8\end{array}$ & $\begin{array}{l}0.58 \\
40.8\end{array}$ & $\begin{array}{l}0.56 \\
51.2\end{array}$ & $\begin{array}{c}0.72 \\
51.1\end{array}$ & $\begin{array}{l}0.75 \\
46.2\end{array}$ & $\begin{array}{r}0.81 \\
42.4\end{array}$ & $\begin{array}{c}0.34 \\
40.1\end{array}$ & $\begin{array}{c}0.37 \\
35.7\end{array}$ & $\begin{array}{l}0.49 \\
39.9\end{array}$ & $\begin{array}{l}0.54 \\
42.8\end{array}$ & $\begin{array}{l}0.73 \\
42.1\end{array}$ & $\begin{array}{l}1.04 \\
40.3\end{array}$ & $\begin{array}{c}1.11 \\
32.9\end{array}$ & & $\begin{array}{l}1.43 \\
41.0\end{array}$ \\
\hline $\begin{array}{l}\mathrm{Ni} \\
\mathrm{Cr} \\
\mathrm{V} \\
\mathrm{Rb} \\
\mathrm{Sr} \\
\mathrm{Y} \\
\mathrm{Zr} \\
\mathrm{Nb} \\
\mathrm{Ba} \\
\mathrm{Th} \\
\mathrm{U} \\
\mathrm{Ta} \\
\mathrm{Hf}\end{array}$ & $\begin{array}{r}38 \\
42 \\
295 \\
48 \\
215 \\
30 \\
150 \\
11 \\
365 \\
= \\
= \\
-\end{array}$ & $\begin{array}{r}46 \\
53 \\
318 \\
18 \\
176 \\
29 \\
106 \\
7 \\
217 \\
= \\
= \\
-\end{array}$ & $\begin{array}{c}59 \\
126 \\
340 \\
14 \\
346 \\
25 \\
127 \\
11 \\
299 \\
2.09 \\
\overline{0.81} \\
3.47\end{array}$ & $\begin{array}{c}66 \\
205 \\
320 \\
10 \\
267 \\
32 \\
145 \\
14 \\
285 \\
2.48 \\
0.66 \\
0.83 \\
3.80\end{array}$ & $\begin{array}{c}58 \\
136 \\
357 \\
34 \\
329 \\
31 \\
163 \\
15 \\
364 \\
3.05 \\
0.67 \\
1.01 \\
4.44\end{array}$ & $\begin{array}{c}35 \\
132 \\
383 \\
24 \\
288 \\
37 \\
169 \\
16 \\
355 \\
2.84 \\
1.62 \\
1.04 \\
4.90\end{array}$ & $\begin{array}{c}29 \\
54 \\
374 \\
34 \\
274 \\
37 \\
188 \\
17 \\
414 \\
3.11 \\
1.29 \\
1.13 \\
5.24\end{array}$ & $\begin{array}{c}35 \\
180 \\
459 \\
37 \\
208 \\
48 \\
236 \\
19 \\
369 \\
3.33 \\
- \\
1.48 \\
6.29\end{array}$ & $\begin{array}{c}33 \\
66 \\
281 \\
36 \\
365 \\
43 \\
232 \\
20 \\
481 \\
4.31 \\
1.47 \\
1.57 \\
5.83\end{array}$ & $\begin{array}{c}37 \\
76 \\
367 \\
27 \\
389 \\
38 \\
198 \\
19 \\
454 \\
3.31 \\
1.16 \\
1.49 \\
5.39\end{array}$ & $\begin{array}{c}28 \\
86 \\
462 \\
27 \\
485 \\
34 \\
220 \\
22 \\
381 \\
3.42 \\
- \\
1.65 \\
6.34\end{array}$ & $\begin{array}{c}21 \\
46 \\
405 \\
29 \\
449 \\
40 \\
242 \\
23 \\
465 \\
3.67 \\
1.00 \\
1.58 \\
7.13\end{array}$ & $\begin{array}{r}14 \\
24 \\
259 \\
39 \\
493 \\
49 \\
336 \\
31 \\
685 \\
5.14 \\
1.21 \\
2.44 \\
9.14\end{array}$ & $\begin{array}{c}74 \\
264 \\
375 \\
41 \\
523 \\
29 \\
205 \\
21 \\
534 \\
4.34 \\
1.10 \\
1.66 \\
5.92\end{array}$ & $\begin{array}{c}41 \\
84 \\
381 \\
44 \\
599 \\
35 \\
283 \\
23 \\
802 \\
4.25 \\
- \\
2.03 \\
7.78\end{array}$ \\
\hline $\begin{array}{l}\mathrm{La} \\
\mathrm{Ce} \\
\mathrm{Nd} \\
\mathrm{Sm} \\
\mathrm{Eu} \\
\mathrm{Tb} \\
\mathrm{Tm} \\
\mathrm{Yb} \\
\mathrm{Lu}\end{array}$ & $\begin{array}{l}\bar{z} \\
\bar{z} \\
\bar{z} \\
\bar{z} \\
\bar{z}\end{array}$ & $\begin{array}{l}\bar{z} \\
\bar{z} \\
\bar{z} \\
\bar{z}\end{array}$ & $\begin{array}{c}16.4 \\
38.2 \\
22.1 \\
4.63 \\
1.61 \\
0.82 \\
0.26 \\
2.47 \\
0.40\end{array}$ & $\begin{array}{c}17.5 \\
41.1 \\
23.0 \\
5.31 \\
1.75 \\
0.92 \\
0.52 \\
3.21 \\
0.53\end{array}$ & $\begin{array}{c}21.4 \\
52.9 \\
29.4 \\
6.44 \\
2.04 \\
0.99 \\
0.56 \\
3.19 \\
0.53\end{array}$ & $\begin{array}{c}21.7 \\
50.5 \\
28.3 \\
6.32 \\
2.05 \\
1.16 \\
0.57 \\
3.78 \\
0.62\end{array}$ & $\begin{array}{c}23.9 \\
56.0 \\
30.8 \\
6.83 \\
2.13 \\
1.15 \\
0.53 \\
3.82 \\
0.63\end{array}$ & $\begin{array}{c}26.3 \\
61.8 \\
35.6 \\
8.25 \\
2.45 \\
1.56 \\
0.48 \\
4.94 \\
0.84\end{array}$ & $\begin{array}{r}34.5 \\
73.9 \\
43.0 \\
9.44 \\
2.95 \\
1.51 \\
0.67 \\
4.15 \\
0.72\end{array}$ & $\begin{array}{l}29.1 \\
62.2 \\
34.2 \\
7.12 \\
2.52 \\
1.28 \\
0.31 \\
3.65 \\
0.58\end{array}$ & $\begin{array}{c}29.4 \\
71.0 \\
43.2 \\
- \\
2.82 \\
1.29 \\
0.61 \\
3.36 \\
0.48\end{array}$ & $\begin{array}{c}33.4 \\
76.3 \\
48.0 \\
- \\
2.94 \\
1.34 \\
0.68 \\
3.53 \\
0.59\end{array}$ & \begin{tabular}{|c}
47.8 \\
112 \\
54.3 \\
- \\
4.10 \\
1.95 \\
0.85 \\
4.48 \\
0.64
\end{tabular} & $\begin{array}{c}71.7 \\
42.2 \\
6.79 \\
2.69 \\
1.19 \\
0.60 \\
2.69 \\
0.47\end{array}$ & $\begin{array}{l}37.3 \\
90.2 \\
46.4 \\
\overline{3} .56 \\
1.56 \\
0.68 \\
2.90 \\
0.39\end{array}$ \\
\hline $\begin{array}{l}\mathrm{Rb} / \mathrm{Sr} \\
\mathrm{Rb} / \mathrm{Y} \\
\mathrm{Ba} / \mathrm{Y} \\
\mathrm{Zr} / \mathrm{Y} \\
\mathrm{Zr} / \mathrm{Nb} \\
\mathrm{La} / \mathrm{Yb}\end{array}$ & $\begin{array}{c}0.223 \\
1.60 \\
12.2 \\
5.00 \\
13.6 \\
-\end{array}$ & $\begin{array}{l}0.102 \\
0.62 \\
7.5 \\
3.66 \\
15.1 \\
-\end{array}$ & $\begin{array}{c}0.040 \\
0.56 \\
12.0 \\
5.08 \\
11.5 \\
6.6\end{array}$ & $\begin{array}{c}0.037 \\
0.31 \\
8.9 \\
4.53 \\
10.4 \\
5.5\end{array}$ & $\begin{array}{c}0.103 \\
1.10 \\
11.7 \\
5.26 \\
10.9 \\
6.7\end{array}$ & $\begin{array}{c}0.083 \\
0.65 \\
9.6 \\
4.57 \\
10.6 \\
5.7\end{array}$ & $\begin{array}{c}0.124 \\
0.92 \\
11.2 \\
5.08 \\
11.1 \\
6.3\end{array}$ & $\begin{array}{c}0.178 \\
0.77 \\
7.7 \\
4.92 \\
12.4 \\
5.3\end{array}$ & $\begin{array}{c}0.099 \\
0.84 \\
11.2 \\
5.40 \\
11.6 \\
8.3\end{array}$ & $\begin{array}{c}0.069 \\
0.71 \\
11.9 \\
5.21 \\
10.4 \\
8.0\end{array}$ & $\begin{array}{c}0.056 \\
0.79 \\
11.2 \\
6.47 \\
10.0 \\
8.7\end{array}$ & $\begin{array}{c}0.065 \\
0.73 \\
11.6 \\
6.05 \\
10.5 \\
9.5\end{array}$ & $\begin{array}{c}0.079 \\
0.80 \\
14.0 \\
6.86 \\
10.8 \\
10.7\end{array}$ & $\begin{array}{c}0.078 \\
1.41 \\
18.4 \\
7.07 \\
9.8 \\
12.7\end{array}$ & $\begin{array}{c}0.073 \\
1.26 \\
22.9 \\
8.09 \\
12.3 \\
12.9\end{array}$ \\
\hline${ }^{87} \mathrm{Sr} /{ }^{86} \mathrm{Sr}$ & - & 0.70659 & 0.70594 & 0.70568 & 0.70567 & 0.70587 & 0.70575 & - & - & 0.70566 & 0.70550 & 0.70546 & - & - & 0.70561 \\
\hline
\end{tabular}

sample analysed was from the same lithological unit. Once 30-50 $\mathrm{g}$ had been sorted, this was washed several times with distilled water in an ultrasonic bath to remove any surface dust and drilling mud, before crushing in an agate ball-mill.

The primary concern was with the reliability of the geochemical data acquired from such samples. Initially, four of the more northern boreholes ("CB", "AN", "RO", "CS") were selected for a reconnaissance study and samples were chosen from approximately $100-150 \mathrm{~m}$ intervals down each hole. Thirty-eight samples were prepared, and major and trace elements were determined on fusion discs and pressed powder pellets by XRF at Nottingham and the Open universities. All major element data have been normalised to $100 \%$ on a volatile-free basis and selected analyses are given in table 2. A smaller selection of samples were also analysed by INAA (Potts et al. 1985) and for $\mathrm{Sr}$ and $\mathrm{Pb}$ isotopes, both at the Open University.

All the lavas analysed are basalts and basaltic andesites with between $48.5 \%$ and $55 \% \mathrm{SiO}_{2}$, and $\mathrm{MgO}$ ranging from $2.7 \%$ to $6.5 \%$. The more mafic basalts still only have $\mathrm{Mg}$ number $<55$ and this, coupled with their low Ni contents ( $<$ $100 \mathrm{ppm}$ ), emphasizes the differentiated nature of these lavas. They display a large range in $\mathrm{TiO}_{2}$ content $(1.4-4.0 \%)$ and also of many incompatible elements such as $\mathrm{Zr}(100-350$ $\mathrm{ppm}), \mathrm{Ba}(130-800 \mathrm{ppm})$, and $\mathrm{Sr}(170-600 \mathrm{ppm})$. The borehole data fall into three distinct groups apparent from the $\mathrm{TiO}_{2}$ vs. MgO plot (Fig. 3) which defines compositional fields having low, intermediate, and high $\mathrm{TiO}_{2}$, analogous to the LPT, IPT, and HPT groups recognised in the surface lavas. Figure 5 also shows the good agreement between the borehole data and average compositions of surface lavas of the three

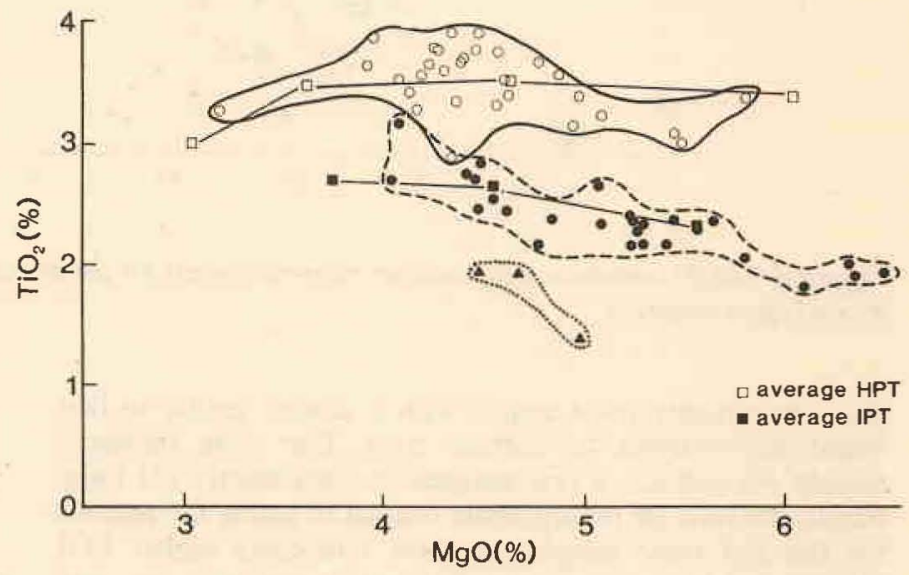

Figure 3 - Variation of $\mathrm{TiO}_{2}$ versus $\mathrm{MgO}$ for the borehole lavas used to delineate the three main magma types: LPT (solid triangles), IPT (solid circles) and HPT (open circles). Averages of surface lavas from central Paraná in Piccirillo et al. (1986) are shown

groups sampled in the central area of the Parana province (Piccirillo et al. 1986).

The good positive correlation between $\mathrm{MgO}$ and $\mathrm{CaO}$ (Fig. $4 \mathrm{~d}$ ) and to a lesser extent $\mathrm{Al}_{2} \mathrm{O}_{3}$ (Fig. 4c), together with the almost constant Sr (Fig. 5c), are consistent with crystal fractionation of a gabbroic assemblage (Cox 1980). On the whole, the major element variations within each group (Fig. 4) 

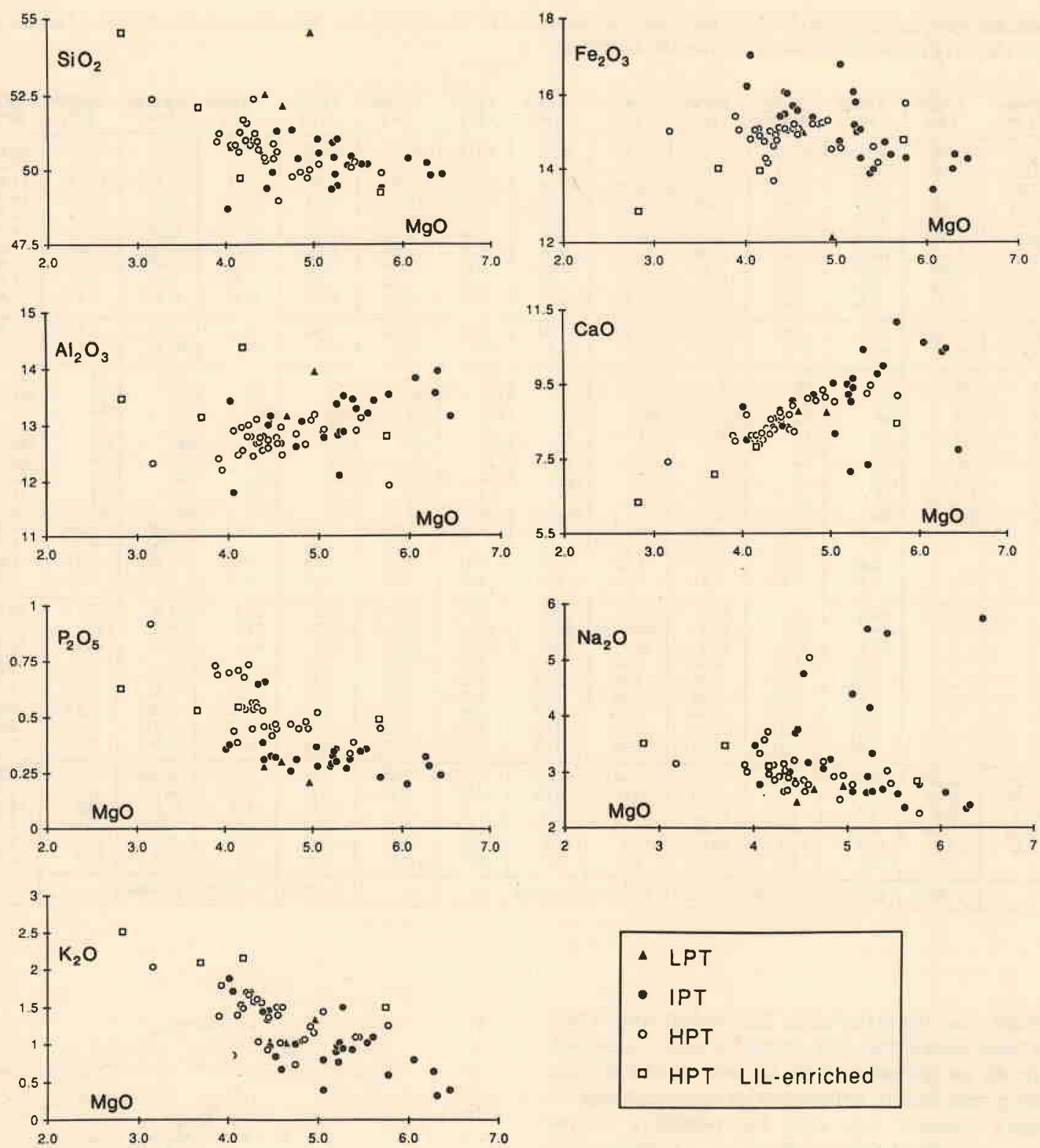

Figure 4-MgO variation diagrams for major elements for the borehole lavas. Symbols are as for figure 3, except HPT LIL-enriched group (open squares)

show remarkably good trends with a scatter similar to that found for analyses of surface lavas. For some elements, namely $\mathrm{Na}$ and $\mathrm{Ca}$, a few samples lie significantly off these trends. There is no petrographic control to assess the reasons for this but these samples do have noticeably higher LOI values $(<1.5 \%)$. The extent of alteration processes can only be assessed qualitatively because of the nature of the samples. Marsh \& Eales (1984) demonstrated that $\mathrm{Na}, \mathrm{K}, \mathrm{Rb}, \mathrm{Sr}$, and $\mathrm{Ba}$ were particularly susceptible to mobilisation during alteration. For the borehole samples, $\mathrm{Rb}$ and $\mathrm{K} 2 \mathrm{O}$ do show a greater scatter, though maintaining an anticorrelation with $\mathrm{MgO}$. The good covariance between $\mathrm{Ba}, \mathrm{Rb}$, and $\mathrm{K} 2 \mathrm{O}$ (Fig. 5f) suggests that the enrichments in these elements are an inherent feature of the geochemical groups and have only been "blurred" by alteration. For trace element variations (Fig. 5 a-e), $\mathrm{Zr}$ is used as a measure of the extent of gabbroic fractionation within each group, as well as emphasizing the varying enrichment between groups.
For the purposes of this study, the petrogenetic significance of the chemical variations in magma composition are not important, but just their usefulness in being able to delineate magma types. Table 3 lists the more useful criteria that distinguish between the various borehole geochemical units.

Within an individual borehole, a consistent stratigraphy is observed and the pattern of IPT lavas overlying a sequence of HPT flows is seen in all four studied boreholes. Lavas of a given magma type occur as a packet of sequential flows, showing each geochemical magma type to form a discrete stratigraphic unit. The distribution of the magma types within the four boreholes is shown in figure 6 . The contact between the two major groups, HPT and IPT, occurs at a successively lower stratigraphic height in each borehole moving northwards; "CS" $750 \pm 100 \mathrm{~m}$, "RO" $325 \pm 40 \mathrm{~m}$, "AN" $-565 \pm 75 \mathrm{~m}$, "CB" $-630 \pm 20 \mathrm{~m}$ (NB this ignores the single HPT flow at $-450 \mathrm{~m}$ ), implying a northerly dip of 

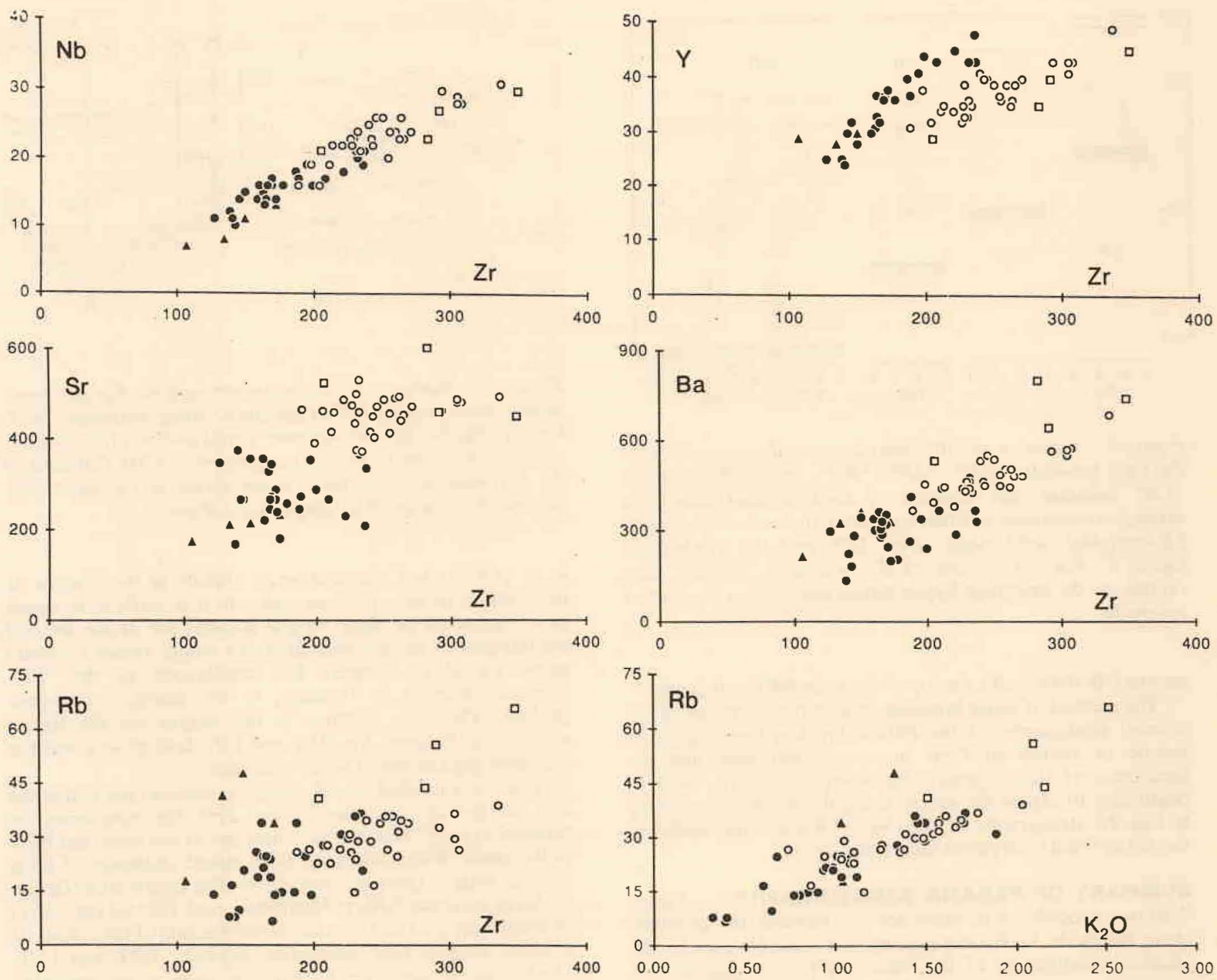

Figure 5 - Trace element variation diagrams for the borehole lavas. a. $\mathrm{Nb}$ (ppm) versus $\mathrm{Zr}$ (ppm); b. $Y$ versus $\mathrm{Zr}$; c. $\mathrm{Sr}$ versus $\mathrm{Zr}$; d. $\mathrm{Ba}$ versus $\mathrm{Zr}$; e. $R b$ versus $\mathrm{Zr}$; f. $R b\left(\mathrm{ppm}\right.$ ) versus $K_{2} \mathrm{O}$ (wt\%). Symbols are as for figure 6

Table 3 - Geochemical criteria used to characterise the various borehole magma types

\begin{tabular}{|c|c|c|c|c|c|c|}
\hline & $\begin{array}{l}\mathrm{TiO}_{2} \\
\mathrm{~W} \% \%\end{array}$ & $\begin{array}{l}\mathrm{SiO}_{2} \\
\mathrm{wW}_{2}\end{array}$ & $\begin{array}{c}\text { St } \\
\text { ppm. }\end{array}$ & $2 \mathrm{r} / \mathrm{Nb}$ & $2 \pi / Y$ & Ba/Y \\
\hline LPT & $<2.0$ & $>520$ & - & $>13$ & - & $<125$ \\
\hline IPT & $1,8-3.2$ & $<51.5$ & $<375$ & $<13$ & $4.0-6.0$ & $<i 25$ \\
\hline HPT & $>2.9$ & - & $>375$ & $<13$ & 5.5-7.5 & $11.0-14.5$ \\
\hline $\begin{array}{l}\text { HPT } \\
\text { Lit-enriched. }\end{array}$ & $>30$ & - & $>440$ & $<13$ & $7.0-8.1$ & $>16.0$ \\
\hline
\end{tabular}

approximately $0.3^{\circ}$. The minor LPT flows that form a unit $350 \pm 60 \mathrm{~m}$ thick at the base of the "CS" borehole could not be traced across to the adjacent "RO" hole. The basal $300 \mathrm{~m}$ here were not sampled because of problems of samples fineness and alteration. It is clear though that the LPT unit dies out moving north. Hence the conclusion that in the central region of the Parana at least, the geochemical formations have a pattern of northwardly dipping units, evolving with time from LPT to HPT to IPT (Fig. 6).

The next stage was to investigate the stratigraphy in greater detail, by more extensive sampling of a single borehole. The "CB" borehole was chosen in view of its location over the deepest known part of the lava pile, cutting through $1,723 \mathrm{~m}$ of basalts (this includes at least $28 \mathrm{~m}$ of sandstone intercalations). In all, 40 samples were analysed from this borehole giving on average one sample per $42 \mathrm{~m}$ of lava. For comparison, lava flows exposed in road sections on the coastal escarpment in Santa Catarina state averaged 20-25 $\mathrm{m}$ in thickness (Peate unpub).

The results reinforced the preliminary stratigraphy shown in the reconnaissance survey, with about $800 \mathrm{~m}$ of IPT lavas overlying a $900 \mathrm{~m}$ thick HPT unit. However, the closer spacing of samples has also brought to light a few anomalies in the sequence, notably at the base of the borehole and at the contact between the HPT and IPT units (Fig. 6). The basal four samples (CB 1776, 1842, 1863A, 1902) form a unit nearly $200 \mathrm{~m}$ thick and have a distinctive chemistry with respect to the overlying HPT lavas. They cover a wide range of compositions with $\mathrm{MgO}$ between $2.8 \%$ and $5.8 \%$, all having high $\mathrm{TiO}_{2}$ (3.1-3.9 wt\%), but are distinguished from the main HPT group by their higher $\mathrm{Ba}, \mathrm{Rb}$, and $\mathrm{K}$ contents, being characterised by $\mathrm{Rb} / \mathrm{Y}>1.2$ and $\mathrm{Ba} / \mathrm{Y}>16$. The formation boundary between the IPT and HPT units is not clearly defined, as lava flows of both types appear interbedded (CB 846, HPT; CB 954, IPT). The samples CB $975 / 1002$ have intermediate $\mathrm{TiO}_{2}(2.75-2.85 \mathrm{wt} \%)$ but have some features more characteristic of the HPT magma type, high $\mathrm{P}_{2} \mathrm{O}_{5}(0.65 \mathrm{wt} \%)$ and higher LREE and Th. The next 


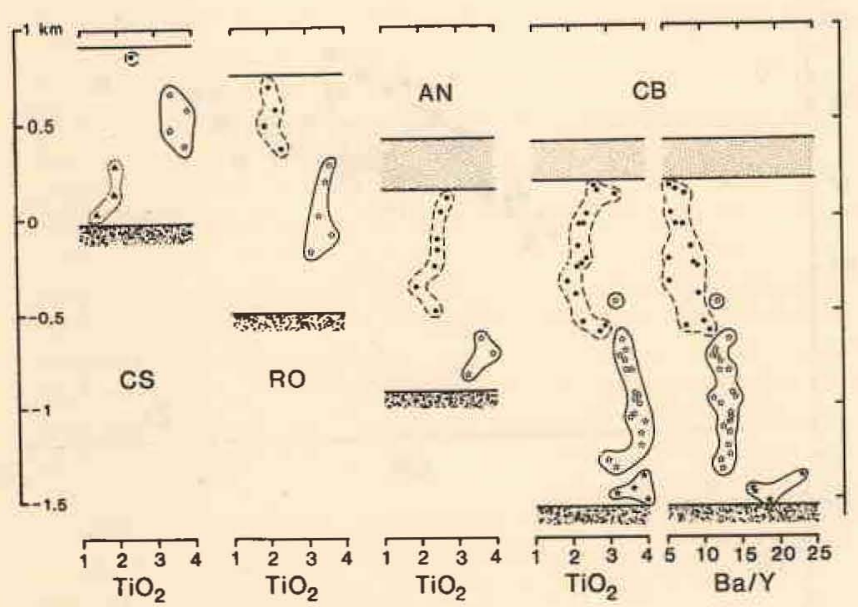

Figure 6 - Variation of $\mathrm{TiO}_{2}$ with elevation above sea level for the four boreholes " $C B$ ", " $A N$ ", "RO", and " $C S$ ". For the " $C B$ " borehole, the variation of $B a / Y$ is also shown, to highlight the difference between the HPT (open stars) and HPT LIL-enriched (solid stars) types. LPT and IPT symbols as figure 3. For " $A N$ ' and " $C B$ " boreholes, stippled area represents the overlying Upper Cretaceous Bauru Formation sediments

sample CB 1047 marks the top of the main HPT unit proper.

The method of using borehole drill chippings to reveal the internal stratigraphy of the Paraná lavas is believed to be unique in studies of CFB provinces, and now that the usefulness of this approach has been established, work is continuing to extend the survey using the southern boreholes to link the stratigraphy of the Central Parana (this study) to the Serra Geral escarpment area in the south.

SUMMARY OF PARANÁ STRATIGRAPHY Figure 7 shows a north-south cross-section through the province along longitude $52^{\circ} \mathrm{W}$, summarising the available data on the chemical stratigraphy of the Paraná CFB. The diagram is a schematic profile, intended to give a synopsis of the general features of the lava field stratigraphy.

The northern part of the cross-section is constrained solely by the available borehole coverage. The profile of lava thickness and depth is taken from oil company well-log charts (Northfleet et al. 1969) that are summarised in figure 2. Over most of the northern area, the lavas are overlain by the Bauru Formation sandstones and siltstones (Table 1; geological map, Shobbenhaus et al. 1984). In this region, the borehole samples have shown a stacking of different magma types all stepping up towards the north. The sequence has IPT lavas overlying HPT which in turn overlie LPT in the more southerly boreholes. This pattern has two main implications for the development of this part of the magmatic province. Firstly, it indicates that the dominant magma type has evolved from LPT to HPT to IPT with time and also suggests that the source of the magmatism might have migrated north. Independent evidence to support this latter conjecture is sparce. There is a suggestion from the published $\mathrm{K}-\mathrm{Ar}$ ages (Bellieni et al. 1983) that in the basin as a whole there was a migration of volcanism from the south-west to the north-east but this is not well constrained. This migration could be related to the northward propagation of rifting during the initiation of the South Atlantic ocean.

The southern half of the profile in figure 7 has been compiled from the lava thickness variations shown in figure 2 , geophysical well-logs and by extrapolation of stratigraphic sequences sampled on the coastal escarpment onto the line of section. The distribution of acidic lavas is from Mantovani

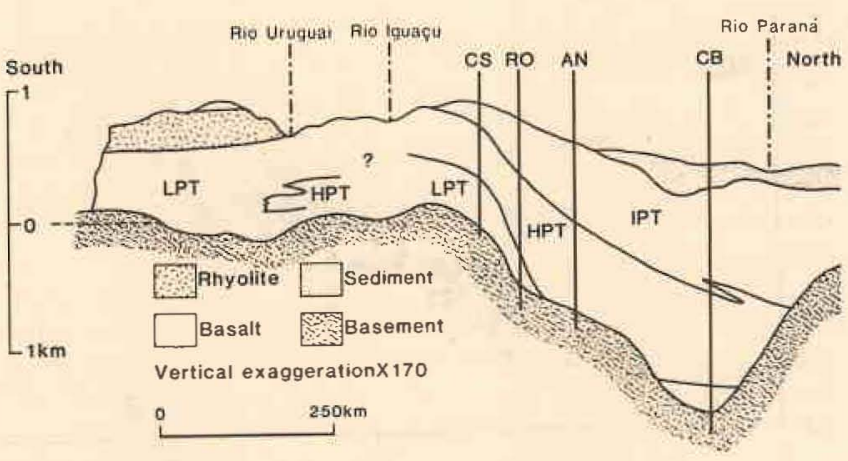

Figure 7 - Summary cross-section through the Paraná continental flood basalts (CFB) province, along longitude $52^{\circ} \mathrm{W}$, highlighting the lithostratigraphic configuration of the various geochemical units (vertical exaggeration $x$ 170). Positions of the boreholes and the three major rivers of the basin (Rio Paràná, Rio Iguaçu, Rio Uruguai) are shown

et al. (1985b) and Horbach et al. (1987). In the absence of information inland of the escarpment, it is difficult to assess how representative these coastal sections are of the internal stratigraphy of the southern area as a whole. Hence it should prove useful to compare the stratigraphy of the "ES" borehole when it is available, to the nearby escarpment profiles. The main features in this region are the spatial relationship between the HPT and LPT lava groups and the extensive thicknesses of acidic volcanics.

There is a marked lateral change in magma type within the lava pile between latitudes $28^{\circ}$ and $29^{\circ} \mathrm{S}$, this zone being the "transition zone" between LPT magmas to the south and HPT to the north. Within this area, thick mixed sequences of lavas of both magma types are developed. The Guata-Bom Jardim da Serra sequence (GB) in Mantovani et al. (1985a) has $630 \mathrm{~m}$ of basalts exposed and contains seven packets of lava flows of a given magma type alternating between HPT and LPT. Moving north along the escarpment, there is an increasing influence of HPT flows. The Rocinha-Encruzilhada (RA) section (Bellieni et al. 1983) contains a single HPT flow in $930 \mathrm{~m}$ of lavas, whereas $75 \mathrm{~km}$ further north in the Urubici area north-east of São Joaquim, HPT lavas dominate the sequences ( $>65 \%$, Peate unpub.). The pattern of distribution of magma types in this area seems to indicate the existence of two separate and simultaneously active vent systems to the north and south of the area, resulting in the side-by-side arrangement of the HPT and LPT units and the observed local interfingering of the two magma types.

The section shows the development of thick sequences of acidic volcanics generally forming the upper portions of the lava pile. These are concentrated along the eastern continental margin of the province, reaching a maximum thickness in the south-eastern corner of $400 \mathrm{~m}$ (Lajeado-Soledade "LS" section; Bellieni et al. 1986). The uppermost parts of the acidic suite are marked by intercalations of basic and/or intermediate flows. Mantovani et al. (1985a, b) recognised two chemically distinct groups within the silicic volcanics, on the basis of their relatively low or high content of $\mathrm{Ti}, \mathrm{P}$ and other incompatible elements ( $\mathrm{Zr}, \mathrm{Nb}$, LREE etc.). Using the terminology of Bellieni et al. (1986), the "Palmas" type (incompatible element poor) are widespread in the southern part of the Paraná Basin and are intimately associated with the LPT basic lavas. Similarly the relatively minor "Chapecó" type (incompatible element rich) reflect the distribution of their association with HPT basaltic lavas and are restricted to the north and central parts of the eastern margin.

The north and south regions of the basin appear to have 
rather different lithostratigraphic patterns of units and the connection between the two is unclear. The northern area has geochemical units overstepping to the north perhaps indicative of a migrating magmatic source. In the south however, two units HPT and LPT lie adjacent to one another, and are interbedded at the contact, suggesting their eruption from separate but contemperaneous fissure systems.

As well as the contrasting stratigraphic styles between north and south, there is also the problem of relating the main magma types over the whole provinces. Initially, the division of the Paraná basalts into geochemical groups was based on their $\mathrm{TiO}_{2}$ content which defined three main groups: LPT $(<$ $2 \%)$, IPT $(2-3 \%)$, and HPT $(>3 \%)$. The basin-wide applicability of these groups is still to be established. Do members of these-groups form a continuous, traceable unit over the province or does each group comprise several magma types that show the same gross features such as high, intermediate or low $\mathrm{TiO}_{2}$ content? This can be illustrated by comparing the HPT rocks from the northern part of the basin (the unit encountered in the boreholes) to those exposed on the northern Serra Geral escarpment in the south-east of the province. There is a noticeable difference in chemical composition of high-Ti lavas between the two areas (Bellieni et al. 1983). For the same MgO content, the southern lavas are enriched over their northern counterparts in $\mathrm{TiO}_{2}, \mathrm{Zr}$, and $\mathrm{Nb}$ by approximately $0.25 \mathrm{wt} \%, 50 \mathrm{ppm}$, and $5 \mathrm{ppm}$ respectively. They also show markedly higher $\mathrm{Sr}$ contents (averages, 750 vs. $450 \mathrm{ppm}$ ) and enrichment in LREE ( $\mathrm{La} / \mathrm{Yb}_{\text {south }} 13-16$ vs. $\mathrm{La} / \mathrm{Yb}_{\text {north }}$ 8-13). Results from the southern boreholes will be needed to check whether there is a discrete boundary between the two types or if the change is gradational from north to south. This will help in deciding whether to consider the two types as distinct geochemical formations or whether it is just a geographically related variation within the same formation. This latter possibility has already been noted in the Deccan continental flood basalts (CFB) sequences by Lightfoot (1985). The Mahabaleshwar Formation in the Central Deccan is distinctive compared to that in the South Deccan but the general style of trace element and isotope enrichments are similar. Lightfoot suggested that while the broad nature of the processes forming the Mahabaleshwar magma type is the same in both areas, there is a more subtle compositional control imposed by the differing magmatic plumbing system that allows variable amounts of contamination, mixing and fractional crystallisation to effect the lavas.

A similar situation is found within the LPT group. In a study of low-Ti lavas from the whole Paraná basin, Petrini et al. (1987) recognised three geochemical groups that were restricted in their distribution within the province. There is a marked difference in incompatible element contents between the north and central Paraná LPT lavas, with the northern lavas more enriched in $\mathrm{K} 2 \mathrm{O}(0.85 \%$ vs. $0.31 \%), \mathrm{Ba}(350$ vs. 180 ppm), $\mathrm{Sr}(290$ vs. $180 \mathrm{ppm}), \mathrm{P}_{2} \mathrm{O}_{5}(0.27 \%$ vs. $0.17 \%)$ etc. Both areas have ${ }^{87} \mathrm{Sr} /{ }^{86} \mathrm{Sr}<0.706$ indicating that they have probably suffered minimal crustal interaction. By contrast, the extensive LPT lavas in the southern Parana show a higher and coherent variation in ${ }^{87} \mathrm{Sr} /{ }^{86} \mathrm{Sr}(0.706-0.712)$ and also higher $\mathrm{SiO}_{2}, \mathrm{~K} 2 \mathrm{O}, \mathrm{Rb}$, and $\mathrm{Ba}$, consistent with crustal contamination processes. How do these various subgroups fit into the general stratigraphic scheme? The connection between the LPT unit at the base of the "CS" borehole and the main mass of LPT lavas in the south is not yet known.

Finally, there is the difficulty of relating the stratigraphy revealed in the boreholes to the surface distribution of lava types. The borehole stratigraphy indicates that the uppermost lavas flows over most of the northern half of the basin should be of IPT affinity. This is clearly not the case as extensive HPT lava sequences and also the occasional LPT flow have been recorded in this region (Petrini et al. 1987). This highlights the lack of three-dimensional control over the stratigraphy. The east-west structure within the lava pile is poorly understood, as none of the boreholes except for "AN" lie significantly off the north-south profile along longitude $52^{\circ} \mathrm{W}$. The depth to the HPT/IPT boundary in this borehole seems to show a slight westerly component of dip which would be consistent with the outcrop of IPT lavas in eastern Paraguay (Bellieni et al. 1986). Geochemical analyses published to date in the literature are rarely accompanied by sample localities, topographic heights, and other stratigraphic information that would help in mapping out the surface outcrop of the geochemical units, and thereby increase our knowledge of the structure in the absence of any borehole control.

DISCUSSION Discussions concerning the geodynamic controls on Paraná magmatism must be based within the context of its wider tectonic setting, namely its association with the break up of Gondwanaland and the initiation of the South Atlantic Ocean. One aspect of this is the age relationship between the continental flood basalts (CFB) magmatism on both continental margins of the South Atlantic to the beginning of sea-floor spreading. The oldest sea floor spreading magnetic anomaly recognised offshore of the volcanism is anomaly M4 off the coast of Namibia (Austin \& Uchupi 1982), which corresponds to an age of 123-127 Ma. $\mathrm{K}-\mathrm{Ar}$ age determinations on the Serra Geral give a range of 115-135 Ma (Melfi et al. 1967) with a peak at 125-130 Ma. The Etendeka lavas in northwest Namibia give similar ages to the Paraná province of 121-135 Ma (Erlank et al. 1984). For the South Atlantic area it seems that the continental flood basalts (CFB) volcanism is coincident with, or just predates, the onset of sea floor spreading.

From palaeomagnetic evidence and the similarities of chemistry and stratigraphy between the two lava sequences, the Etendeka lavas can be considered as a minor remnant of the more extensive Paraná volcanism. The basaltic lavas are found over a wide area, greater than $1,200,000 \mathrm{~km}^{2}$, and their distribution was not controlled by the location of eventual plate separation but apparently by the position of the preexisting Palaeozoic sedimentary basin. This has resulted in the marked asymmetry of the Paraná-Etendeka province with respect to the opening of the South Atlantic. However, in contrast to this, the later silicic volcanics are preferentially located adjacent to the continental margins in both south-east Paraná and Etendeka. The LPT rhyolites of south-east Paraná have elevated ${ }^{87} \mathrm{Sr} /{ }^{86} \mathrm{Sr}$ but their origin from a semi-continuous $\mathrm{AFC}$ process is inconsistent with the relative absence of intermediate lavas within the lava sequence. Therefore, Hawkesworth et al. (1988) considered the rhyolites as crustal melts, as earlier suggested by Cordani $e t$ al. (1980). Erlank et al. (1984) also suggested a crustal anatexis model to explain the quartz latites of the Etendeka region. This would require elevated temperatures at or near the base of the crust, localised along the developing plate boundary. Moreover, the disparity between the distribution of acidic and basaltic lavas indicates that the higher crustal temperatures were not simply the result of intrusion of basic magmas (Duncan et al. 1984), and the additional thermal input needed could have come from the rising asthenosphere accompanying the incipient rifting process. Continental flood basalts (CFB) magmatism in such a thinned lithosphere/rift environment is characterized by a sequence of flood basalts of enriched "lithospheric" character followed by abundant silicic volcanism (Marsh 1987). After extensive thinning or rupture of the lithosphere, the later stages are marked by basalts of depleted character derived from the upwelling asthenosphere. The Etendeka lava sequence is cross-cut by late-stage dykes, the Horingbaai dolerites that have MORB-like characteristics, and basalts sampled offshore of the south-east Brazilian 
continental margin show the transition from continental flood basalts (CFB) to MORB-like compositions (Fodor \& Vetter 1984).

Studies of the earlier Karoo magmatism in South Africa (185-195 Ma; Fitch \& Miller 1984) are pertinent to any discussion regarding a geodynamic framework for the Paraná event. Duncan et al. (1984) concluded that the Karoo basalts were not a direct consequence of the disruption of Gondwanaland but a common process could be responsible for both events (and likely for the Paraná as well).

Three different geodynamic mechanisms have been proposed to account for the extensive Mesozoic continental flood basalts (CFB) provinces that outcrop in the southern hemisphere: i. "Hot spot"; ii. "Subduction related"; iii. insulation model". Morgan (1982) extrapolated modern day ocean island "hot spots" to their palaeopositions beneath the continents in Mesozoic reconstructions. From this he appealed to the coincidence of the Paraná-Etendeka lavas and the Karoo volcanics in the Central and Lebombo areas to the Tristão da Cunha and the Crozet "hot spot" respectively, to argue for a plume origin for the continental flood basalt (CFB) magmatism. Initiation of a "hot spot" beneath the continental flood basalt (CFB) magmatism as the "hot spot" sub-continental lithosphere over 10-30 Ma, resulting in continental flood basalt (CFB) magmatism as the "hot spot" track moved away. Duncan et al. (1984) rejected a "hot spot" model for the Karoo continental flood basalts (CFB) but said it was more satisfactory in explaining the Paraná-Etendeka area. Recently, Fodor (1987) has developed this idea relating the geochemistry of the LPT and HPT groups to differing amounts of partial melting and crustal interaction depending on distance from the Tristão da Cunha "hot spot". Directly above the "hot spot", higher degrees of partial melting ( $25 \%$ ) would lead to LPT magmas whereas towards the edge of the plume, lower degrees of melting would result in IPT ( $20 \%$ ) and HPT ( 11\%) magmas. A stratigraphic transition of LPT to IPT to HPT would be expected as the plate migrated away from the "hot spot". The sequence seen in the boreholes of IPT overlying HPT which overlie LPT is difficult to reconcile with this model.

Cox (1978) noted the alignment of the Paraná, Karoo, and Ferrar-Tasmania continental flood basalt (CBF) provinces forming a broad band parallel to the Pacific margin of a reconstructed Gondwanaland, along which subduction had occurred at least since Devonian times. Froidevaux \& Nataf (1981) have shown that large convective "rolls" will develop on the continental side of a subduction zone. The upwelling limbs of these subduction-induced rolls would lie about $3,000-4,000 \mathrm{~km}$ inland of the subduction zone, taking about $200 \mathrm{Ma}$ to establish, consistent with the age and location of the flood basalts, and lead to a widespread heating of the sub-continental lithosphere. This is the view favoured by Duncan et al. (1984) for the Karoo lavas, especially in explaining the generation in a relatively short line span of basaltic magmas over an extensive area.

Anderson (1982) argues that the former presence of the large super-continent Pangea had an insulating effect, allowing an increase in temperature of the sub-continental mantle. This could lead to a pervasive style of melting of the lithospheric mantle which is more consistent with the large scale extent of these continental flood basalts (CFB) provinces (Marsh in prep.). As soon as continental rifts and seafloor spreading are established, the magmatism in the "a-tectonic" continental interiors will decrease due to the increased role of the asthenospheric mantle in convecting heat away trough mid-ocean ridges.

For the Paraná, it is still early days, and deciding between these models depends on their being able to explain the overall structure of the province in terms of its geochemical stratigraphy, the age distribution of units, and the geometry of the dyke feeder system. Much work is still needed to clarify areas of the chemical stratigraphy. A detailed stratigraphically controlled $\mathrm{K}-\mathrm{Ar}$ study is needed to evaluate any migration in the volcanism that could be related to the movement of the Tristão "hot spot" or the propagation of rifting of the South Atlantic ocean, as well as in relating the timing of coastal uplift, continental flood basalts (CFB) magmatism and the onset of rifting.

Acknowledgements Petrobrás (Supex-5148/85) and Paulipetro (Dr. Júlio A. Bruno) for sample donation and for providing essential information through internal reports. Tim Brewer (Nottingham) and John Watson (Open) for XRF analyses. Nick Rogers for INAA analyses and helpful comments on the manuscript. CNPq and British Council provided travel grants for MSMM and CJH. DWP acknowledges a NERC research studentship.

\section{REFERENCES}

AMARAL, G.; CORDANI, U.G.; KAWASHITA, K.; REYNOLDS, J.H. - 1966 - Potassium-argon dates of basaltic rocks from southern Brazil. Geoch. Cosmoch. Acta, 30:159-189.

ANDERSON, D.L. - 1982 - Hot spots, polar wander, Mesozoic convection and the geoid. Nature, 297:391-393.

AUSTIN JR., J.A. \& ICHUPI, E. - 1982 - Continental-oceanic crustal transition off Southwest Africa. Amer. Assoc. Petrol. Geol. Bull. 66:1328-1347.

BEANE, J.E.; TURNER, C.A.; HOOPER, P.R.; SUBBARAO, K.V.; WALSH, J.N. - 1986 - Stratigraphy, composition and form of the Deccan basalts, Western Ghats, India. Bull. Volcanol., 48:61-83.

BELLIENI, G.; BROTZU, P.; COMIN-CHIARAMONTI, P.; ERNESTO, M.; MELFI, A.J.; PACCA, I.G.; PICCIRILLO, E.M.; STOLFA, D. - 1983 - Petrological and palaeomagnetic data on the plateau basalt to rhyolite sequences of the Southern Paraná Basin (Brazil). An. Acad. brasil. Ciênc., 55:355-383.

BELLIENI, B.; COMIN-CHIARAMONTI; P.; MARQUES, L.S ; MELFI, A.J.; PICCIRILLO, E.M.; NARDY, A.J.R.; ROISENBERG, A. - 1984 - High- and low $\mathrm{TiO}_{2}$ flood basalts from the Paraná plateau (Brazil): petrology and geochemical aspects bearing on their mantle origin. Neues. Jb. Miner. Abh., 150:273-306.

BELLIENI, B.; BROTZU, P.; COMIN-CHIARAMONTI, P.; ERNESTO, M.; MELFI, A.J.; PACCA, I.G.; PICCIRILLO, E.M. - 1984 - Flood basalt to rhyolite suites in the southern Paraná plateau (Brazil): palaeomagnetism, petrogenesis and geodynamic implications. J.Petrol., 25:579-618.
BELLIENI, B.; COMIN-CHIARAMONTI, P.; MARQUES, L.S.; MELFI, A.J.; NARDY, A.J.R.; PAPATRECHAS, C.; PICCIRILLO, E.M.; ROISENBERG, A.; STOLFA, D. - 1986Petrogenetic aspects of acid and basaltic from the Parana plateau (Brazil): geological, mineralogical and petrochemical relationships. J.Petrol., 27:915-944.

BELLIENI, G.; COMIN-CHIARAMONTI, P.; MARTINEZ, L.A.; MARQUES, L.S.; MELFI, A.J.; NARDY, A.J.R.; PICCIRILLO, E.M.; STOLFA, D. - 1986 - Continental flood basalts from the central-western regions of the Paraná plateau (Paraguay and Argentina): petrology and petrogenetic aspects. Neues. Jb. Miner. $A b h,, 154: 111-139$.

CORDANI, U.G.; SARTORI, P.L.; KAWASHITA, K. - 1980 Geoquímica dos isótopos de estróncio e a evolução da atividade vulcânica na Bacia do Paraná (sul do Brasil) durante o Cretáceo. An. Acad. brasil. Ciênc., 52:811-818.

COX, K.G. - 1978 - Flood basalts, subduction and the break-up of Gondwanaland. Nature, 274:47-49.

COX, K.G. - 1980 - A model for flood basalt vulcanism. J. Petrol., 21:629-650.

COX, K.G. \& HAWKESWORTH, C.J. - 1985 - Geochemical stratigraphy of the Deccan Traps at Mahabaleshwar, Western Ghats, India, with implications for open system magmatic processes. J. Petrol., 26:355-377.

DEVEY, C.W. \& LIGHTFOOT, P.C. - 1986 - Volcanological and tectonic control of stratigraphy and structure in the western Deccan Traps. Bull. Volcanol., 48:195-207. 
DUNCAN, A.R.; ERLANK, A.J.; MARSH, J.S. - 1984 - Regional geochemistry of the Karoo igneous province. Spec. Publ. geol. Soc. S. Afr., 13:355-388.

ERLANK, A.J.; MARSH, J.S.; DUNCAN, A.R.; MILLER, R. McG.; HAWKESWORTH, C.J.; BETTON, P.J.; REX, D.C. - 1984 Geochemistry and petrogenesis of the Etendeka volcanic rocks from SWA/Namibia. Spec. Publ. geol. Soc. S. Afr., 13:195-245.

FITCH, F.J. \& MILLER, J.A. - 1984-Dating Karoo igneous rocks by the conventional $\mathrm{K}-\mathrm{Ar}$ and ${ }^{40} \mathrm{Ar} / 39 \mathrm{Ar}$ age spectrum methods. Spec.Publ. geol. Soc. S. Afr., 13:247-266.

FODOR, R.V. \& VETTER, S.K. - 1984 - Rift zone magmatism: petrology of basaltic rocks transitional from continental flood basalts (CBF) to MORB, southeastern Brazil margin. Contrib. Mineral. Petrol., 88:307-321.

FODOR, R.V.; CORWIN, C.; ROISENBERG, A. - 1985 - Petrology of Serra Geral (Paraná) continental flood basalts, southem Brazil: crustal contamination, source material, and South Atlantic magmatism. Contrib. Mineral. Petrol 91:54-65.

FODOR, R.V. - 1987 - Low - and high-TiOz flood basalts of southern Brazil: origin from picritic parentage and a common mantle source. Earth Planet. Sci. Lett., 84:423-430.

FROIDEVAUX, C. \& NATAF, H.C. - 1981 - Continental drift: What driving mechanism? Geol. Rdscg, 70:166-176.

HAWKESWORTH, C.J.; MANTOVANI, M.S.M.; PEATE, D.W. 1988 - Lithosphere remobilisation during Paraná magmatism. $J$. Petrol., 29 (in press).

HORBACH, R.; KUCK, L.; MARIMON, R.G.; MOREIRA, H.L.; FUCK, G.F.; MOREIRA, M.L.O.; MARIMON, M.P.C.; PIRES, J. de L.; VIVIAN, O.; MARINHO, D. de A.; TEIXEIRA, W. 1987 - Folha SH22 Porto Alegre e parte da Folha SH21 Uruguaiana e SJ22 Lagoa Mirim. Secretaria do Planejamento da Presidència da República, Fundação Instituto Brasileiro de Geografia e Estatística (IBGE). (Lev. Rec. Nat. 33).

LEINZ, V.; BARTORELLI, A.; SADOWSKI, G.R.; ISOTTA, C.A.L. - 1966 - Sobre o comportamento especial do trapp basáltico da Bacia do Paraná. Bol. Soc. Bras. Geol., 15:79-91.

LIGHTFOOT, P. - 1985 - Isotope and trace element geochemistry of the South Deccan Lavas. (Ph.D. Thesis Open University) (unpub.).

MAACK - 1952 - Die Entwicklung der Gondwana Schichten Suedbrasiliens und ihre Beziehungen zur Karru Formation, Suedafrikas. Int. Geol. Congr. Alger., 19:333-372.

MANTOVANI, M.S.M. - 1985 - Caracterização isotópica do magmationo da Bacia do Paraná, sua correlação com a crosta continental subjacente e com a abertura do Atlantico Sul. (L.D. Thesis São Paulo University) (unpubl.).

MANTOVANI, M.S.M.; MARQUES, L.S.; DE SOUSA, M.A.; CIVETTA, L.; ATALLA, L.; INNOCENTI, F. - 1985a - Trace element and strontium isotope constraints on the origin and evolution of Paraná continental flood basalts of Santa Catarina state (Southern Brazil). J. Petrol., 26:187-209.

MANTOVANI, M.S.M.; CORDANI, U.G.; ROISENBERG, A. $1985 \mathrm{~b}$ - Geoquímica isotópica em vulcânicas ácidas da Bacia do Paraná, e implicaçōes genéticas associadas. Rev. Bras. Geoc., 15:61-65.

MANTOVANI, M.S.M.; PEATE, D.W.; HAWKESWORTH, C.J. 1988 - Geochemical stratigraphy of Paraná Continental Flood Basalts: a contribution from borehole samples. In: PICCIRILLO, E.M.; MELFI, A.J.; eds. The Mesozoic flood volcanism from the Parant Basin (Brazil): petrogenetic and geophysical aspects. Instituto Astronômico e Geofísico, University of São Paulo (in press).
MARSH, J.S. Very large continental flood basalt provinces: emplacement and possible origin. (In prep.).

MARSH, J.S. \& EALES, H.V. - 1984 - The chemistry and petrogenesis of igneous rocks of the Karoo central area, Southern Africa. Spec. Publ. geol. Soc. S. Afr., 13:27-67.

MARSH, J.S. - 1987 - Basalt geochemistry and tectonic discrimination within continental flood basalt provinces. J. Volcanol. Geotherm. Res., 32:35-49.

MELFI, A.J. - 1967 - Potassium-argon ages for core samples of basaltic rocks from southern Brazil. Geochim. Cosmochim. Acta, 31:1079-1089.

MORGAN, W.J. - 1982 - Hot spot tracks and the opening of the Atlantic and Indian oceans. 443-487 In: EMILIANI, C. ed. The sea, vol. 7, The oceanic lithosphere. John Wiley \& Sons, New York, $1,738 \mathrm{pp}$.

NORTHFLEET, A.A.; MEDEIROS, R.A.; MUHLMAN, H. - 1969 Reavaliação dos dados geológicos da Bacia do Paraná. Bol. Tec. Petrobrás, 12:291-346.

PAULIPETRO $=1982$ - Geologia da Bacia do Paraná: reavaliaçăo da potencialidade e prospectividade em hidrocarbonetos. Consórcio CESP/IPT, 198 pp.

PETRINI, R.; CIVETTA, L.; PICCIRILLO, E.M.; BELLIENI, G, COMIN-CHIARAMONTI, P.; MARQUES, L.S.; MELFI, A.J. 1987 - Mantle heterogeneity and crustal contamination in the genesis of low-Ti continental flood basalts from the Paraná plateau (Brazil): $\mathrm{Sr}-\mathrm{Nd}$ isotope and geochemical evidence. $J$. Petrol., 28:701-726.

PICCIRILLO, E.M.; MELFI, A.J.; COMIN-CHIARAMONTI, P.; BELLIENI, G.; ERNESTO, M.; MARQUES, L.S.; NARDY, A.J.R.; PACCA, I.G.; ROISENBERG, A.; STOLFA, D. - $1986-$ Continental flood volcanism from the Paraná Basin, Brazil. In: MacDOUGALL ed. Flood basalts (in press).

POTTS, P.J.; WILLIAMS-THORPE, O.; ISAACS, M.C.; WRIGHT, D.W. - 1985 - High-precision instrumental neutro-activation analysis of geological samples employing simultaneous counting with both planar and coaxial detectors. Chem. Geol., 48:145-155.

SCHNEIDER, R.L.; MUHLMAN, M.; TOMAZI, E.K.; MEDEIROS, R.A.; DAEMON, R.F.; NOGUEIRA, A.A. - 1974 - Revisäo estratigráfica da Bacia do Paraná. In: CONGR. BRAS. GEOL. 28, Porto Alegre, 1974. Anais... Porto Alegre, SBG. v. 1, p. 145-155.

SHOBBENHAUS, C.; ALMEIDA CAMPOS, D. de; DERZE G.R.; ASMUS, H.E. - 1984 - Geologia do Brasil. Texto explicativo do Mapa Geológico do Brasil e da área oceânica adjacente incluindo depósitos minerais. Escala 1:2.500.000. DNPM, Brasília.

SWANSON, D.A.; WRIGHT, T.L.; HOOPER, P.R.; BENTLEY, R.D. - 1979 - Revisions in stratigraphic nomenclature of the Columbia River Basalt group. U.S. Geol. Surv. Bull., 1457-G:1-59.

ZALAN, P.V.; WOLFS, S.; CONCEICĀO, J.C. de J.; ASTOLFI M.A.M.; VIEIRA, I.S.; APPIS, V.T.; ZANNOTTO,O.A. - 1987 - Tectônica e sedimentação da Bacia do Paraná. In: SIMP. SULBRAS. GEOL., 3, Curitiba, 1987. Resumos e Roteiros de excursão... Curitiba, SBG. 30-3. 